\title{
LEISURE AND ITS USE FOR SENIORS WITH VISUAL IMPAIRMENT
}

\author{
Jana Lopúchová \\ Doc. PaedDr, Univerzita Komenského v Bratislave, \\ e-mail: lopuchova@fedu.uniba.sk, Slovakia \\ Žofia Ondráčková \\ PhD., Mgr., Univerzita Komenského v Bratislave, Slovakia
}

\begin{abstract}
The scientific study is devoted to the issue of leisure activities for seniors with visual impairment. The period of life of individuals with visual impairments in postproductive age is characterized by many specificities as well as special needs. Many experts are interested in the saturation of these needs, but it is desirable if a person fulfills his / her goals based on his / her own motivation and possibilities and satisfies their special needs with his / her own activity. Given that older people are more likely to spend a lot of time on their own interests, we have tried to find out in our research how they spend their free time and what are the barriers to active leisure.
\end{abstract}

Keywords: senior, aging, visual impairment, leisure time.

DOI: http://dx.doi.org/10.23856/3711

Publikácia je čiastkovým výstupom projektu VEGA 1/0582/18 Identifikácia, analýza a deskripcia špeciálnych edukačných potrieb jednotlivcov so zdravotným znevýhodnením v produktívnom veku v procese objektívnej a subjektívnej evaluácie možností ich d'alšieho vzdelávania na Slovensku - výskumná analýza.

Vol'ný čas l'udí je v súčasnosti v popredí záujmu mnohých odborníkov, najmä psychológov, sociológov, ale aj pedagógov, príp. špeciálnych pedagógov. U posledne zmienených môžeme pozorovat', že jedným z bodov ich záujmu je vol'ný čas jednotlivcov so zdravotným znevýhodnením, ich možnosti (ovplyvnené druhom a stupňom postihnutia) a spôsoby trávenia vol'ného času.

Pri istej simplifikácii by sme mohli povedat', že vol'ný čas je ten časový úsek, ktorý ostáva človeku po vykonaní nevyhnutných činností (spánku, jedenia, cestovania do zamestnania, práce v domácnosti a pod.) a ktorú človek zvyčajne využíva na regeneráciu svojich síl alebo na saturáciu svojich potrieb, príp. osobnostný rozvoj. Možnosti využivania vol’ného času u intaktných jednotlivcov sú vel'mi rôznorodé nielen čo do počtu, ale aj vo svojej rôznorodosti. Človek sa môže záujmovo vzdelávat', navštevovat' kultúrne, spoločenské, politické ai. aktivity, starat' sa o svoju rodinu, vyrábat' rôzne produkty alebo tvorit' hodnoty, športovat', kreatívne sa prejavovat', stretávat' sa s priatel'mi, alebo jednoducho pasívne odpočívat'.

Definícia vol'ného času podla (Hájeka, Hofbauera, Pávkovej, 2008: 13) hovorí o tom, že ,vol'ný čas je doba, kedy si môžeme svoje činnosti slobodne vybrat', robíme ich dobrovol'ne a radi, prináśajú nám pocit uspokojenia a uvolnenia. “

V Pedagogickom slovníku (Průcha, Walterová, Mareš, 2003: 274.) nachádzame vymedzenie vol'ného času ako „čas, s ktorým človek môže nakladat' podl'a svojho uváženia a na základe svojich záujmov. Vol'ný čas je doba, ktorá zostane z 24 hodín bežného dňa po 
odčitani času venovaného na prácu, starostlivost' o rodinu a domácnost', starostlivost' o vlastné fyzické potreby (vrátane spánku).

Podl’a Pávkovej et al. (2001) vol'ný čas v sebe združuje pojmy odpočinok, rekreácia, zábava, záujmové činnosti, dobrovol'né vzdelávanie a spoločensky prospešná činnost'. Charakterizuje ho sloboda výberu vol'nočasových aktivít, ktorých realizácia sa spája $\mathrm{s}$ pozitívnymi pocitmi.

Hodnotu vol’ného času si uvedomovali mnohí odborníci už pomerne dávno. Už pred približne pät'desiatimi rokmi francúzsky sociológ definoval vol'ný čas ako obdobie, ked' človek vykonáva činnosti podl'a svojej vôle, bud' aby si oddýchol, zabavil sa, alebo rozvinul svoje povolaním nezainteresované znalosti, tvorivé schopnosti, či svoju dobrovol'nú účast' na spoločenskom živote potom, ked' si splnil všetky svoje pracovné, rodinné a spoločenské povinnosti (Dumazedier, 1966).

Chápanie vol’ného času je v každom období života odlišné, a mení sa aj spôsob, akým ho využívame. Ak však človek príde o zrak, ako jeden z dial'kových zmyslov, ktorým získava najväčšie množstvo informácií, pomerne výrazne sa okrem iného menia aj jeho možnosti trávenia vol'ného času. Či už človek stratí zrak v neskoršom veku, alebo so zrakovým postihnutím žije celý život, je zrejmé, že spôsob, akým strávi svoj vol'ný čas v seniorskom veku sa bude od vidiacich l'udí odlišovat'. Nemusí to však byt' odlišnost' len v negatívnom zmysle slova. Práve vol’ný čas seniorov je témou tejto štúdie.

Zrakové postihnutie mnoho l'udí považuje za jednu z najväšších bariér, ako byt' aktívnym. Laici sú často krát mediálne informovaní len o „reprezentujúcich“ lud’och s postihnutím, ako sú napr. paralympionici, umelci, speváci a pod. Avšak je pozitívne, že títo jednotlivci sa vo vol’nom čase zaoberajú množstvom rôznych aktivít a záujmov. S rozvojom digitálnych technológií sú im ponúkané nové možnosti, a aj seniori so zrakovým postihnutím dnes dokážu mnohé technológie využívat' naplno a zefektívnit' tak trávenie svojho vol'ného času.

Táto problematika je v referenčnom poli pedagogiky zrakovo postihnutých spracovaná fragmentárne, a tak zostáva dostatočne vel'ký priestor na skvalitňovanie a kompletizáciu poznatkov v záujme komplexnosti problematiky.

\section{Seniori a proces starnutia}

Starnutie je prirodzený, celý život prebiehajúci proces, ktorý zasahuje do života každého jednotlivca, začína sa narodením, aj ked’ výraznejšie involučné zmeny nastávajú až vo vyššom veku, kedy sa objavujú typické prejavy starnutia. Staroba je spojená nielen so zmenami biologickými, ale nastáva pri nej aj vel’a dôležitých sociálnych zmien.

Problém vymedzit' presný vek začiatku staroby súvisí podla Stuart-Hamiltona (1999) s tým, že starnutie je kontinuálny proces, ktorý nie je l'ahké rozdelit'. Podla Jakabčica (2002) v rámci organizmu nestarnú všetky jeho orgány a funkcie rovnomerne, ale môže sa vyskytovat' výrazná intraindividuálna variabilita. Mühlpachr (2004) uvádza, že vo väčšine prípadov sa hranica staroby posúva $\mathrm{k}$ hodnote 65 rokov a je pravdepodobné, že v budúcnosti sa bude postupne ešte zvyšovat' podobne ako dôchodkový vek, resp. populačný vek.

Starnutie obyvatel'stva má vplyv aj na zvýšený výskyt a charakter zrakového postihnutia vo svete. Svetová zdravotnícka organizácia (WHO) systematicky zhromažd’uje všetky dostupné údaje o celosvetovej prevalencii a príčinách zrakového postihnutia. Odhaduje, že pokial' sa neurobia opatrenia na prevenciu a liečbu hlavných príčin zrakového 
postihnutia, bude sa počet nevidiacich vo veku 50 a viac rokov celosvetovo zvyšovat' (Visual Impairment and Blindness, 2010).

Súčasný stav a jeho smerovanie teda prináša výzvy aj pre špeciálnu pedagogiku vo sfére starostlivosti o starších l'udí so zrakovým postihnutím a zabezpečenia čo najvyššej kvality života týchto jednotlivcov, či už postihnutie získali počas života, alebo sa ich postihnutie zhoršilo v dôsledku starnutia.

\section{Dôsledky straty alebo poškodenia zraku v seniorskom veku}

Zmeny v zrakovom vnímaní u seniorov môžu byt' spôsobené bud' samotným fyziologickým starnutím - ide o gerontologické zmeny, alebo sa môžu vyskytnút' tzv. geriatrické zmeny, ktoré súvisia s morfologickými zmenami na oku a pôsobia pre človeka rušivo. Fyziologické starnutie oka sa najčastejšie prejavuje stratou pružnosti šošovky, ktorá je spojená s poklesom až stratou akomodácie. Tento jav sa označuje ako presbyopia a ide o prirodzenú súčast' procesu starnutia. Šošovka postupne stráca schopnost' prispôsobit' sa videniu do blízka a zabezpečit jasný obraz. Pokles schopnosti akomodácie sa kompenzuje dioptrickými okuliarmi - pridaním dioptrií (Oláh, 2005). Medzi d’alšie a časté pričiny zrakového postihnutia u seniorov patrí vekom podmienená degenerácia makuly, refrakčné chyby, glaukóm, katarakta a diabetická retinopatia (Gerinec, 2005).

Zhoršenie zraku až úplné znemožnenie zrakového vnímania výrazne zasahuje do života človeka vo všetkých oblastiach a prináša množstvo nových problémov, s ktorými sa musí vyrovnávat'. Seniori patria $\mathrm{v}$ tomto ohl'ade $\mathrm{k}$ špecifickej skupine, pretože u nich prirodzeným starnutím prebiehajú aj mnohé d’alšie zmeny, ktoré sa u detí, mládeže a l'udí stredného veku neobjavujú.

Seniori so zrakovým postihnutím sú podl'a odborníkov viac vystavení hrozbe sociálnej izolácie. Vplyvom zhoršeného vizuálneho vnímania často strácajú pocit bezpečia, nemôžu sa plne spoliehat' na svoje zmysly, dochádza u nich k stavom neistoty a úzkosti. Starší človek sa môže ocitnút' v situácii, kedy trpí nielen postihnutím zraku, ale oslabujú sa aj d’alšie zmyslové funkcie, a tým sa napr. znižuje jeho schopnost' orientácie. Môže dôjst' k frustrácii a rezignácii, človek sa prestane pokúšat' o udržiavanie predošlého spôsobu života a upadne do pasivity (Klevetová, Dlabalová, 2008).

Strata zraku predstavuje pre staršieho človeka tiež nevyhnutnost' vysporiadat' so zát'ažou spôsobenou stratou očakávaní a predstáv o spôsobe, ako strávi svoju starobu. Stereotyp, na ktorý bol počas svojho života zvyknutý sa zrazu zmení, a zvládanie každodenných povinností sa naraz môže stat' vel'kou výzvou, niekedy len t'ažko zvládnutel'nou. Problémom je aj nuda a strata niektorých vol’nočasových aktivít (Cory in Wahl, Schulze, 2001).

Stratou zraku mnoho zrakovo postihnutých môže príst' o množstvo sociálnych kontaktov naviazaných najmä na prácu alebo dovtedajšie aktivity. Tým sa sociálna izolácia prehlbuje, čo môže viest' niekedy až k depresii. Ďalším faktorom, ktorý je v tomto období pre nevidiaceho človeka dominantný, je postoj spoločnosti. Aj ked' v posledných rokoch sme zaznamenali výrazný posun najmä vd’aka forsírovanej integrácii/inklúzii, stále sú prítomné stigmatizujúce prvky, ako napr. dlhá biela palica, vodiaci pes, špeciálne okuliare, sprievodca ai., ktoré sú pre spoločnost' prvkom odlišnosti, v tých horších prípadoch aj prvkom nedocenenia nevidiacich a vnímania ich ako menejcenných, resp. nepotrebných. Tieto zaužívané stereotypy môžu tejto minoritnej skupine výrazne škodit'. 


\section{Vol’ný čas seniorov}

Vol'ný čas nie je iba súhrnom rôznych samostatných aktivít, ale má význam ako dôležitá súčast' životného štýlu každého jednotlivca. Spokojnost' s vol’ným časom je pozitívne spojená s kvalitou života starších l'udí (Roelofs, 1999).

Účast' na vol'nočasových aktivitách je spojená s úspešným starnutím, predovšetkým $\mathrm{s}$ fyzickým zdravím a subjektívnou pohodou (Depp, Jeste, 2006).

Podl'a štúdie Pressmanovej et al. (2009) je subjektívna pohoda pozitívne spätá s frekvenciou, v akej sa senior zapája do vol'nočasových aktivít, ktoré mu prinášajú potešenie.

Odchodom do dôchodku sa človeku často otvoria mnohé možnosti, na ktoré v produktívnom veku nemal čas alebo energiu. Je to zmena, ktorá ovplyvní nielen jeho fyzické fungovanie, ale najmä psychiku. Toto obdobie však prináša aj isté riziká, napr. najmä u aktívnych seniorov pocit nepotrebnosti a neužitočnosti.

To, ako človek trávi vol'ný čas, ovplyvňujú mnohé faktory. Medzi nimi napr. faktory vyplývajúce $\mathrm{z}$ procesu starnutia (v starobe dochádza k mnohým zmenám organizmu, ktoré môžu byt' fyziologickým prejavom starnutia, ale príčinou býva aj prítomnost' choroby, ktorá sa u starších l'udí nezriedka pridružuje a jej výskyt je typický práve v starobe); polymorbidita; úroveň mobility; správanie sa starších l'udí a menšia schopnost' prispôsobit' sa novým okolnostiam, reagovat' na zmeny; zmeny v oblasti kognitívnych funkcií - oblast' percepcie, oblast' pozornosti, oblast' pamäti, oblast' rozumových schopností (Vágnerová, 2008). Dalej sú to doba vzniku postihnutia, druh a stupeň postihnutia, osobnostné charakteristiky, úroveň vzdelania, úroveň jeho nadobudnutých kompetencií (vrátane špecifických kompetencií), adaptácia na postihnutie, jeho akceptácia, podpora rodiny a okolia a tiež charakter záujmov a vykonávaných záujmových činností pred stratou zraku.

Existuje ešte vel'ké množstvo faktorov, ktoré determinujú možnosti a spôsoby, akými budú seniori svoj vol'ný čas trávit'. Mali by sme však počítat' s istou ,,personalizáciou“, teda tým, že každý jednotlivec je entita, bio-psycho-sociálna bytost’ a teda aj rozdiely v trávení vol'ného času u zrakovo postihnutých seniorov budú vysoko špecifické.

\section{Vymedzenie výskumného problému}

Vol’ný čas je pre každého z nás významným časovým intervalom, kedy venujeme čas sebe a našim záujmom. Aj napriek dôležitosti problematiky je táto na Slovensku spracovaná len fragmentárne. V oblasti pedagogiky zrakovo postihnutých je empirických výstupov ešte menej. Aj toto bol dôvod, prečo sme sa spoločne s Ondráčkovou (2017) venovali výskumnému zist'ovaniu spôsobov trávenia vol’ného času seniormi so zrakovým postihnutím a deskripcii špecifík vol'nočasových aktivít u týchto jednotlivcov.

Zaujímalo nás, ako strata zraku ovplyvnila trávenie ich vol'ného času, akým spôsobom trávia seniori so zrakovým postihnutím svoj vol'ný čas, čo pre nich tento čas predstavuje, ako sú spokojní s využitím ich vol'ného času, ktoré vol'nočasové aktivity sú pre nich dostupné a pod.

Výskumný súbor pozostával zo šiestich participantov so zrakovým postihnutím. Všetci participanti mali 60 a viac rokov, štyri boli ženy a dvaja muži. U participantov v rámci diagnóz prevládala praktická slepota (až u piatich participantov) a jeden bol úplne nevidiaci. 


\section{Údaje o participantoch}

Tab. 1

\begin{tabular}{|c|c|c|c|c|c|}
\hline Participant & Pohlavie & Vek & $\begin{array}{c}\text { Stupeň zníženia } \\
\text { vizuálnych } \\
\text { schopností }\end{array}$ & $\begin{array}{c}\text { Postihnutie podl'a } \\
\text { doby vzniku }\end{array}$ & $\begin{array}{c}\text { Stav } \\
\text { postihnutia }\end{array}$ \\
\hline P1 & žena & 76 & praktická slepota & vrodené & $\begin{array}{c}\text { mierne } \\
\text { progresívny }\end{array}$ \\
\hline P2 & žena & 64 & praktická slepota & získané & $\begin{array}{c}\text { mierne } \\
\text { progresívny }\end{array}$ \\
\hline P3 & žena & 66 & praktická slepota & vrodené & $\begin{array}{c}\text { mierne } \\
\text { progresívny }\end{array}$ \\
\hline P4 & muž & 72 & úplná slepota & získané & ustálený \\
\hline P5 & žena & 73 & praktická slepota & $\begin{array}{c}\text { vrodená } \\
\text { predispozícia }\end{array}$ & $\begin{array}{c}\text { mierne } \\
\text { progresívny }\end{array}$ \\
\hline P6 & muž & 60 & praktická slepota & vrodené & ustálený \\
\hline
\end{tabular}

Hlavnou metódou, ktorú sme využili na získavanie dát, bola metóda pološtruktúrovaného interview. Pomocou tejto metódy sme sa snažili zistit' potrebné informácie a zároveň pozorovat' participanta pri jeho výpovedi - najmä mimiku, gestiku, proxemiku a iné nonverbálne prejavy alebo doplnkové zvuky. Výsledky sme vyhodnocovali prostredníctvom metódy obsahovej analýzy a metódy in vivo kódovania, výsledkom ktorej bolo vo finále vykreovaných šest' významových kategórií.

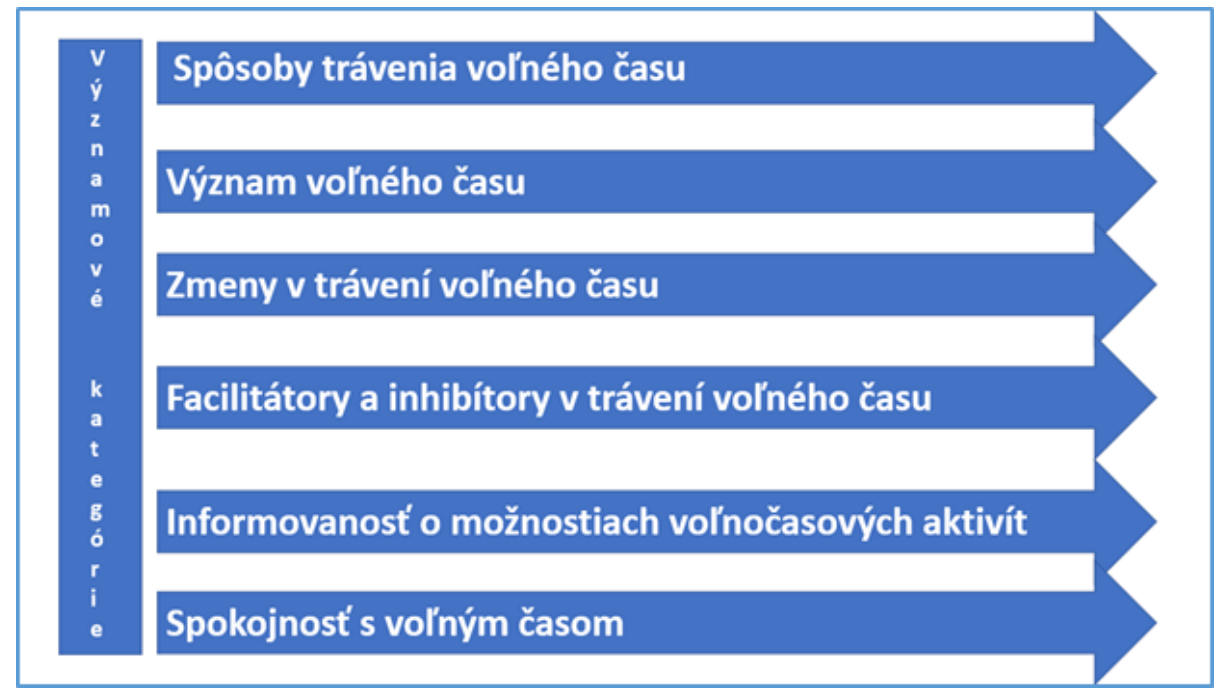

\section{Schéma 1 Významové kategórie}

\section{Spôsoby trávenia vol’ného času}

Využitie vol'ného času jednotlivými participantmi sa odlišovalo, avšak našli sa aj aktivity, ktorým sa rovnako venovali všetci alebo väčšina participantov. Participanti radi 
trávili čas najmä s druhými l’ud'mi, či už s det'mi, vnúčatami, známymi alebo susedmi. Často sledujú televíziu, alebo počúvajú rádio. Viacerí participanti uviedli, že trávia svoj vol'ný čas v prírode. Všetci participanti potvrdili, že sa vo vol'nom čase stretávajú aj s d’alšími l'ud'mi so zrakovým postihnutím, najčastejšie $\mathrm{v}$ rámci akcií organizovaných ÚNSS, napr. návštevy divadla, koncertov, výletov, zájazdov alebo besied. Výraznejšie rozdiely sme zistili najmä u participantov P2 a P4, ktorých spájala aktívna spolková činnost'. Zatial' čo ostatní participanti sa vyjadrili, že majú dost' vol'ného času, niektorým sa zdalo, že až príliš, P2 a P4 to vnímali odlišne. P2 má pocit, že má nedostatok vol’ného času, pretože má vel'mi vel’a aktivít, a množstvo času jej zaberie organizácia činnosti spolkov a taktiež pomoc iným l'ud'om so zrakovým postihnutím. P4 sa o svojej činnosti v rámci organizácie pre l’udí so zrakovým postihnutím vyjadril, že ,...ja to urobím vo volnom čase, ale ono sa to tak namnožilo, že vlastne áno, je to v poriadku, robím to, venujem sa tomu, ale je to svojím spôsobom na úkor tých vecí, čo by som chcel robit' vo vol'nom čase. "

P1 sa vyjadrila, že okrem toho, že občas ide k lekárovi alebo upratuje, má ,...stále čas pre seba..." Vo vol’nom čase počúva rádio, pozerá televíziu, venuje sa vnúčatám, cestuje, chodí na zájazdy s ÚNSS. Rada trávi čas so svojimi det'mi, ,potom tu s l'ud'mi z Únie, a najmä so susedou, s tou som skoro každý den̆. Rada trávim čas s druhými l’ud'mi. "Uvádza, že v súčasnosti trávi svoj vol'ný čas skôr pasívne.

P2 trávi vol’ný čas „úplne aktívne“ a každý deň sa venuje množstvu aktivít. Má rada prírodu, chodí na výlety, poznávacie zájazdy, venuje sa športovým aktivitám, navštevuje kultúrne podujatia, vel'a času venuje pomoci druhým l'ud'om: ,...ten čas vždy aj na tých l'udí treba mat' nejaký.“ Chvílu času pre seba má iba večer, ,od tej desiatej zhruba to už do tej jednej, preto nerada chodím skoro spat', lebo vtedy sa mi zdá, že už je také vákuum, už tam komunikujem len so synom nanajvýš alebo s mužom, že vtedy už je naozaj taký klud od tej desiatej do tej jednej, preto mi je l'úto vždy ist'spat. "“

P3 uvádza, že „času mám až vel'a niekedy. “ Hovorí, že doobeda sa venuje domácnosti a „...poobede mám len vol’ný čas.“ Obl'ubuje trávit' čas vonku, venuje sa turistike, chodí na prechádzky sama alebo s kamarátkou, navštevuje kultúrne podujatia, lúšti krížovky, číta, venuje sa ručným prácam, pozerá televíziu. Rada trávi vol’ný čas v prírode a v záhradke. Vel’a času však trávi sama, čo vníma ako negatívum. Vyjadrila túžbu trávit' svoj čas aktívnejším spôsobom, pretože momentálne vníma samú seba ako dost' pasívnu.

P4 trávi vol'ný čas aktívnym spôsobom. ,...za aktívne považujem trebárs to čitanie a prácu s počitačom, lebo tie zručnosti, to človek musí mat' neustále na zreteli. "Okrem toho má oblubuje rýchle prechádzky, turistiku, cestovanie na miesta, ktoré poznal ešte ako vidiaci, prednášky a besedy o astronómii, genealógiu a históriu. Týmto témam sa vo vol'nom čase aktívne venuje, pracuje napríklad na genealógii svojej rodiny. $\mathrm{S}$ vnukom rád diskutuje o spoločných témach, napríklad o fyzike či astronómii.. Rád sa príležitostne venuje aj drobným opravám, alebo práci v záhrade.

P5 je vo vol’nom čase aktívna, chodieva na prechádzky, má rada prírodu, vel'a cestuje a chodieva na pobyty, niekedy navštevuje divadlo, zúčastňuje sa besied a aktivít organizovaných ÚNSS. Vel'mi dôležitá je pre ňu rodina, deti, vnuci, pravnuci. Využitie vol'ného času v prípade participantky závisí od jej aktuálneho naladenia: „,...niekedy vstanem ráno a cítim sa velmi zle, takže...tá aktivita je to potom minimálna."

P6 má „,...vel'a vol’ného času.“ Chodieva na prechádzky, počúva rádio a televíziu, navštevuje koncerty, divadlo, cestuje, chodieva von s priatel’mi, alebo trávi čas so susedmi. Dost' času venuje aj spolkovej činnosti. Aktivity nemá rozložené rovnomerne: „,...niekedy sa nudím, niekedy nie, ono je, že...niekedy je toho dost." “ 


\section{Význam vol’ného času}

Dôležitou funkciou vol’ného času na základe odpovedí viacerých participantov je rozptýlenie, či už v zmysle oslobodenia sa od starostí a problémov života, alebo v zmysle zahnania nudy a zabavenia sa. P1, ktorá je rada vo vol’nom čase $\mathrm{v}$ spoločnosti druhých, povedala: „....nemusím stále uvažovat' nad niečim, čo by ma ubíjalo... aktivitami vo volnom čase sa odpútavam od samoty, ja nemám rada samotu, neznášam ju. " P2 podobného oslobodenia sa dociel'uje pozeraním dobrých filmov: „...skrátka sa dostanem do úplne iného prostredia. Potom rozmýšl'am nad tým, čo sa udeje, ten dej, sa tak vžijem do toho, hlavne do romantík. “ 44 opísal svoje pocity takto: „...niekedy ma taká situácia, ktorú považujem za volnočasovú aktivitu tak opantá, ako ked' si dáte čokoládu, a poviete, dám si jeden štvorček, a zjete ju nakoniec celú. “Pre P3 má vel'ký význam trávenie vol’ného času s l'ud’mi: „...prídem na iné myšlienky, aj sa dozviem vel’a nových vecí, a ja rada porozprávam, poprechádzame sa... Tak, vel'mi rada idem medzi l'udí, to je jasné. " P6 zase aktivitami vo vol'nom čase bojuje proti nude, najmä ked’ môže trávit' čas v spoločnosti druhých.

Participanti vidia význam vol’nočasových aktivít v ich sebarealizácii ,...takého druhu, ktoré by som v rámci povinných povinností, teda to, čo musím, nemohol "; je pre nich dôležité potešenie $z$ úspechu, najmä pri činnostiach, ktoré ako vidiaci vedeli vykonávat' bez problémov; v nadobudnutí pocitu štastia: ,...ked’ som sama a idem na nejakú prechádzku, je to úžasné, mám rada ticho, a rada sledujem zelen̆, hocijakú, sledujem, čo môžem ,vidiet"“, a teším sa z toho, mám pocit štastia “; pocitu spokojnosti, naplnenia, možnosti trávit' vol’ný čas podla ich vlastných predstáv ,...je to úžasné, ked’ viem, že ten vol'ný čas si môžem spravit' a mám ho, že ma nikto neobmedzuje. “

\section{Zmeny v trávení vol’ného času}

Strata zraku je vel'kým, prevažne negatívnym zásahom do fungovania $v$ bežnom živote a často krát znemožňuje vykonávanie mnohých aktivít. Vo výskume, ktorý realizovali Phoenix, Griffin a Smith (2015), participanti najčastejšie uvádzali šoférovanie a čítanie, ručné práce, či loptové hry ako príklady činností, ktoré kvôli svojmu postihnutiu nemôžu realizovat'. Vel'ký dopad na spôsob trávenia vol'ného času mala smrt' partnera, ktorý pre jednotlivcov predstavoval oporu pri vykonávaní aktivít. Bez jeho pomoci sa stali pasívnejšími. V dôsledku straty zraku sa predížil aj čas potrebný na realizáciu vol’nočasových činností.

Pri interview s našimi participantami sme sa zameriavali najmä na zmeny spôsobené zrakovým postihnutím, avšak $\mathrm{z}$ rozhovorov vyplynuli aj d’alšie významné faktory, ovplyvňujúce zmeny v oblasti vol'ného času u seniorov so zrakovým postihnutím.

Všetci participanti sa vyjadrili, že zrakové postihnutie ovplyvnilo aj ich vol’ný čas, avšak miera tohto zásahu bola participantami vnímaná odlišne. Najmenšie zmeny pocitoval P6, ktorý povedal, že pred zhoršením zrakového postihnutia mohol čitat', ale inak nespomenul žiadne aktivity, o ktoré by bol ukrátený. O svojom vol'nom čase sa vyjadril takto: ,...ja v podstate môžem všetko vykonávat', ja nemám problémy s tým, lebo mña ked' niekto zoberie pod pazuchu a ideme von, môžem ist' všade." Zmeny vnímal skôr kvôli odchodu zo zamestnania, ,...lebo človek ked' robi, tak zas má úplne iný život.“ Avšak na druhú stranu, ako participant povedal, „...ja mám l’udí okolo seba, takže mne v podstate to nerobilo problém“. Podla jeho slov po odchode $\mathrm{z}$ práce to ,mal také individuálne, že väčsinou doma, na Úniu som moc nechodil “. Po tom, čo začal zastávat' funkciu v ÚNSS, má opät' viac aktivít. 
Ostatní participanti však vnímali vplyv zrakového postihnutia na oblast' ich vol'nočasových aktivít výraznejšie. Viacerí uviedli, že v súčasnosti nemôžu čítat' a venovat' sa ručným prácam, čo pre nich boli činnosti, ktorým sa predtým venovali vo vel'kej miere. P5 povedala, že kvôli zhoršeniu zraku sa v jej vol'nom čase zmenilo „...vel'mi vel'a, lebo ja som vel'a pracovala s hlinou, či šitie, či vyš́vanie, či štrikovanie, všetko toto dneska nemôžem robit. Čo je vel'mi obmedzujúce. Čítala som vel'mi vel'a kníh." P4 sa pred stratou zraku venoval lúšteniu krížoviek, a našiel si náhradu v zist'ovaní informácií o l'ud'och, ktorí ho niečím zaujali.

Svoju úlohu pri výbere a vykonávaní aktivít zohráva podl'a výpovedí viacerých participantov aj strach, čo má na oblast' vol'ného času limitujúci efekt.

Vol’ný čas participantov sa menil aj v súvislosti so starnutím. P1 svoju situáciu zhrnula takto: „Pozitívom súčasnej situácie je, že mám viacej vol’ného času, a trávim ho pasívnejšie, lebo už tých aktivit nemám tol'ko, to je vekom prirodzené. " Podl'a P5 starnutie spôsobuje, že človek má menej času: „...človek čím je starš́i, tým toho času je menej, pretože viac mu trvá niečo urobit', viac času potrebuje na úkony... “”

Významný zásah do spôsobu prežívania vol'ného času predstavovala smrt' životného partnera. P1 zmenu opísala: „Ked' som bola s manželom, tak tých možností som mala vel'a. Tým, že je človek sám, lebo som vdova, tak ho nič nebaví. “

\section{Facilitátory a inhibítory v trávení vol'ného času}

Výskumy poukazujú na fakt, že účast' na vol'nočasových aktivitách môže byt' pre seniorov so zrakovým postihnutím výzvou. Seniori udávajú väčšie obmedzenia v porovnaní so seniormi bez zrakového postihnutia pri návšteve kina, verejných rekreačných miest, účasti na náboženských podujatiach, stolovaní v reštaurácii (Alma et al., 2011; Crews, Campbell, 2004). Phoenix, Griffin a Smith (2015) zistili, že dostupnost' dopravy predstavuje častú prekážku pri vykonávaní aktivít. Niektorí seniori sa vzdali aktivít tiež z dôvodu vel'kej vzdialenosti a náročnosti na čas. Problém predstavoval aj zlý zdravotný stav, závislost' od pomoci rodiny či okolia, či fyzické bariéry v prostredí.

Je jednoznačné, že zrakové postihnutie vplýva na rozsah možností, ktoré sa v rámci vol'ného času naskytujú. P1 si myslí, že „....ked' sa zhorši zrak, tak je menej možností. “ Podl'a P5 „,bariéry sú vel'mi vel'ké dá sa povedat', pretože nemôžete chodit' ako normálny človek, že niekde chcete ist', nemôžete sa všade dostat'. “

Participanti nemali pocit, že by bolo málo možností, ako trávit' vol'ný čas. Niektorí participanti však mali na mysli skôr všeobecnú existenciu potenciálnych možností, ktoré nie vždy reálne využívali, alebo ich z nejakého dôvodu nepovažovali vo svojom prípade za dostupné. Podl'a P1: „Keby človek chcel, tak by mal dost’ možností.“ Čo sa týkalo jej vlastných možností, mala pocit, že by ich bolo viac, keby nebola sama. P3 sa vyjadrila vel'mi podobne: „No možností by bolo, možno že ich nevyužívam. “ Dôvody nevyužívania, ktoré uviedla, zahŕňali hlavne problémy pri cestovaní a samotu. Pridávame aj názor P5: „,..keby som sa snád' viacej zaujímala, viacej by som tých možností mala. " Povedala, že už má vytvorený vlastný okruh aktivít, s ktorými je spokojná, preto sa o d'alšie nezaujíma. Možnosti teda z pohl'adu participantov jestvujú, avšak záleží od samotného jednotlivca, do akej miery sa bude aktívne snažit' získat' $\mathrm{k}$ nim prístup. V konečnom dôsledku je dôležitá hlavne subjektívna spokojnost’ človeka, ktorou sa zaoberáme nižšie.

Participanti sa v priebehu interview zmienili o činnostiach, ktoré by chceli vykonávat', ale ku ktorým mali st’ažený alebo znemožnený prístup. Prirodzene, existujú obmedzenia, 
ktoré vyplývajú z povahy postihnutia a spočívajú $\mathrm{v}$ nemožnosti venovat' sa napríklad spomínanému čítaniu, ručným prácam, či šoférovaniu. Strach, o ktorom sme sa zmieňovali vyššie, môže tiež predstavovat' bariéru, vyplývajúcu z postoja a povahy človeka. Okrem toho sa vyskytlo viacero aktivít, ktorým by sa participanti napriek svojmu postihnutiu venovat' mohli, ale ich dostupnost' nebola taká, ako by si želali. Príčinou bolo napríklad to, že k ich realizácii potrebovali d’alšieho človeka. P4 považoval nevyhnutnost' vykonávat' niektoré záujmové aktivity s pomocou druhej osoby za limitujúcu pri dosahovaní vytýčeného ciel'a.

P6 svoje možnosti zhodnotil celkovo pozitívne, $\mathrm{k}$ čomu z vel'kej časti prispievala skutočnost', že má okolo seba známych, ktorí mu umožňujú venovat' sa rôznym vol'nočasovým aktivitám. Okrem medzil'udského kontaktu môže byt' pri rozširovaní vol'nočasových možností nápomocná aj technika, ktorú hojne využíval P4: „počitač, to je kvalitná optika, pre mňa je volný čas aj vtedy, ked’ sedím pri počitači, a napriklad skenujem knihy. Počitač mi otvára svet, otvára mi obzory. "Istý limit však participant videl v tom, že pri jeho používaní je viazaný na konkrétne miesto.

\section{Informovanost' o možnostiach vol'nočasových aktivít}

V oblasti informovanosti sa opät' vyjadrenia participantov rozchádzali. P2, P3 a P6 mali pocit, že ich informovanost' o možnostiach je dostatočná, a P1, P4 a P5 vyjadrili názor, že informácií by mohlo byt' viac. Jednotliví participanti uviedli rôzne pričiny nízkej informovanosti. P1 udala ako dôvod to, že nemá prístup k internetu, P4 sa vyjadril, že hoci informácie si dokáže pohl'adat', niektoré mu práve kvôli zrakovému postihnutiu unikajú. Na ilustráciu uviedol príklad televízie: „...televíziu nesledujem, ale počúvam. Dávajú nejakú informáciu, ale telefónne čislo je na obrazovke. Ale to ani nepovedia, že je tam čislo. Alebo, bude relácia, taká a taká, a povedia akurát deñ, a ten čas, o kolkej, je tam napisaný. Proste toto sú už veci, ktoré by sa asi mohli brat'v úvahu, ale neberú sa. "Opät' ide o situáciu, v ktorej by problém vyplývajúci zo zrakového postihnutia mohol byt' prekonaný, avšak d’alšie okolnosti tomu nie sú priaznivo naklonené. $\mathrm{V}$ tomto prípade sú z pohladu participanta príčinou l'udia, ktorí na potreby zrakovo postihnutých neberú dostatočný ohl'ad, hoci riešenie problému existuje. Aj P5 vyjadrila názor, že ,...dalo by sa viacej pomôct' l'ud'om s postihnutím..."

\section{Spokojnost' s vol’ným časom}

Väčšina participantov sa vyjadrila o svojej spokojnosti pomerne kladne, aj ked’ takmer každý by uvítal možnost' istých zmien v spôsobe, akým svoj vol’ný čas trávi. P1 povedala: „Ja som spokojná ako ho trávim, dá sa povedat', lebo si vždy niečo nájdem, aby som ho nejako trávila. "Zároveň však spomenula, že jej chýba niekto, s kým by svoj vol'ný čas mohla prežívat', a to jej bráni $\mathrm{v}$ spokojnosti. Išlo o protirečiace názory, dalo by sa $\mathrm{z}$ nich však vyvodit', že hoci niektoré okolnosti bránia $\mathrm{v}$ naplnení predstáv participantky o vol’nom čase, snaží sa o pozitívny prístup. Na otázku, či by niečo chcela zmenit' na spôsobe, akým trávi vol'ný čas, odpovedala: ,...už ani nie, lebo ja už mám taký svoj kolobeh, že mi to vyhovuje. Ked' chcem, tak zavolám niektorej kamarátke a porozprávame sa a hotovo. “ Pre P2 je spokojnost' spojená so splnením toho, čo si určila: „Ked’ stihnem všetko čo naplánujem, tak som velmi spokojná. “ Dôležitá je pre ňu aj sloboda vo výbere: „,...môžem niečo uprednostnit', môžem niečo zavrhnút, niečo zrušit' alebo nahradit', takže to je dobre." Ako negatívum vnímala hlavne nedostatok vol’ného času. Keby mohla, viac by sa venovala kultúrnym 
aktivitám, avšak pocit’uje silný záväzok voči l’ud’om, ktorí očakávajú jej pomoc, preto jej na spomenuté aktivity nezostáva tol'ko času. P4 vyhovuje, ako trávi vol'ný čas, pretože, ako povedal: „...keby som bol nespokojný, tak by som hladal nejaké iné spôsoby. A keby som $k$ tomu dospel, názoru, tak bez problémov to urobím. " $\mathrm{Z}$ výpovede $\mathrm{P} 4$ vidiet', že k svojmu vol'nému času zaujíma aktívny postoj. Ohl'adom želaných zmien v spôsobe trávenia vol'ného času povedal: ,...73 rokov už je tak dostatočný vek, aby človek začal ukrajovat' z toho času pre iných, a že aby sa venoval takým aktivitám, čo jeho tešia. Proste, myslím si, že do takého stavu prenikám... "V jeho prípade by teda išlo o zmenu reálne dosiahnutel'nú, v čom sa líši od väčšiny ostatných participantov. Vo výpovediach P5 sa objavoval motív vd'ačnosti a prijímania pozitívnej stránky veci: „,..áno, dalo by sa to aj inak, ale, spokojná som s tým, že aspoň takto sa to dá. Niekedy sa vel'mi hnevám na to, že mi to nejde, ale potom sa ukludním a poviem, d'akujem, že vidím aspoň to, čo vidím. Štrikovanie nie je podstatné. Ak by mohla, rada by zmenila spôsob, akým trávi vol'ný čas: „Určite by som vel'a zmenila, vel'a by som zmenila, tým, keby som lepšie videla, vel'a. Viacej by som bola aktívnejšia... " P6 pôsobil ohl'adom svojho vol'ného času jednoznačne najspokojnejšie spomedzi všetkých participantov: „Tak ja mám všetko dobré, pozitívne, no ja nemôžem sa st'ažovat’. Aj predtým bolo dobre, aj teraz je dobre. “ Jeho optimistické naladenie súvisí jednak s tým, že participant má „l'udí okolo seba, človek musí mat' l'udi “, a zároveň s pripravenostou participanta v otázke prognózy postihnutia: ,...chodil som k profesorovi XY do štátnej školy, a ten mi hovoril: jedného dňa ráno sa môžeš zobudit' a oslepneš, tak sa pripravuj na to! Vždy ma na to pripravoval. Aby som počital s tým, takže ja som bol ako pripravený na to, že tie oči pôjdu dole vodou, skôr či neskôr. “Vyjadril sa, že na spôsobe, akým trávi vol'ný čas „,...sa nedá nič menit', lebo hovorím, že mám toho dost', takže menit' sa nedá... “ Naopak, P3 sa na svoju spokojnost' s vol'ným časom pozerala skôr negatívne: „Nie [som spokojná]. Mohla by som ho aj lepšie využit’. Pomaličky si musím zvykat'." Aktuálny pohl'ad participantky na jej vol'ný čas súvisí pravdepodobne s vel'kou životnou zmenou, ktorou bola strata životného partnera a ktorú prekonala len nedávno: „...stále myslite len na chorobu, ešte toho manžela, to je ešte dost' čerstvé. Vel'a vol’ného času mi vyskočilo, lebo som sa musela o manžela starat', bol ležiaci, zrazu bum..." Predtým bola zvyknutá s manželom cestovat', a momentálne, ako sme už spomínali, sú jej možnosti dopravy obmedzenejšie, čo takisto negatívne vplýva na jej vnímanie vol'ného času. Na novú situáciu sa potrebuje adaptovat', ale snaží sa k nej postavit' pozitívne a neupadat' do pasivity. Vyjadrila sa, že by chcela viac využívat' aktivity organizované ÚNSS. Výpovede participantov demonštrujú, aký dôležitý je proces adaptácie na zmeny $\mathrm{v}$ živote človeka, či už ide o zrakové postihnutie, alebo hocijakú inú závažnú udalost'.

\section{Vyhodnotenie výsledkov výskumu a diskusia}

Ciel'om, ku ktorému sme smerovali v našom výskume, bolo zistit', ako seniori so zrakovým postihnutím trávia volný čas a aké špecifiká vo sfére vol’ného času týchto jednotlivcov existujú. Aj ked' výsledky výskumu vzhl'adom na počet participantov nemôžeme zovšeobecnit' $\mathrm{s}$ univerzálnou platnost'ou, napriek tomu z výskumu vyplynulo niekol'ko zaujímavých zistení.

Seniori so zrakovým postihnutím sa venujú širokej škále vol'nočasových aktivít a väčšina pristupuje k svojmu vol'nému času aktívne. Využívajú možnosti, ktoré im ponúkajú suportívne inštitúcie, najmä poznávacie zájazdy, návštevy divadla, besedy, koncerty a výlety. 
Spôsoby trávenia vol’ného času sa u participantov odlišujú, prevažujú prechádzky v prírode, stretnutia s l'ud’mi, či už so zrakovým postihnutím alebo nie, počúvanie rádia a „sledovanie“ televízie. Zrakové postihnutie špecificky ovplyvňuje vol’ný čas každého z participantov, hoci konkrétna miera, v ktorej sa tento vplyv prejavuje, závisí od viacerých faktorov, hlavne stupňa zrakového postihnutia, sociálneho zázemia a postoja samotného jednotlivca. Celkovo hodnotia svoj vol'ný čas participanti skôr pozitívne, k prípadným nedostatkom sa snažia stavat' rozumovo a s nadhl'adom.

Pre všetkých participantov mal vol’ný čas, respektíve aktivity $\mathrm{v}$ rámci neho uskutočňované, nemalý význam. Prostredníctvom nich sa odpútavali od starostí, ktoré v živote prežívajú, či už im k takému úniku pomáhal film, alebo rozhovor s kamarátkou. Vd’aka vol'nočasovým aktivitám prechádzajú nude a samote, umožňujú im získat' nové poznatky a informácie, sebarealizovat' sa. Využívanie vol’ného času podla ich predstáv im prináša pocit spokojnosti, dôležitá je aj sloboda $\mathrm{v}$ rozhodovaní sa o možnostiach využitia vol'ného času. Vd'aka niektorým aktivitám, ktorým sa participanti venujú, získavajú určitý pocit užitočnosti.

Prekážky, ktoré participanti popisovali, pramenili často z dôsledkov samotného zrakového postihnutia. Museli prestat' vykonávat' niektoré aktivity, ktorým sa predtým venovali, alebo sa nimi mohli zaoberat' len v obmedzenej miere. Vyskytoval sa aj strach, jednak ako obava, že kvôli st’aženému vizuálnemu vnímaniu dôjde k úrazu alebo inému nepríjemnému zážitku, ale išlo aj o strach zo zhoršenia poruchy zraku následkom nevhodnej aktivity, napríklad športu. Niektorí participanti mali dojem, že kvôli zhoršenému vizuálnemu vnímaniu nemôžu byt' natol'ko aktívni vo svojom vol’nom čase ako by chceli, čo súviselo hlavne s limitmi pri činnostiach, ktorým sa venovali v minulosti. Ťažkosti spôsobovala aj odkázanost' na druhých l'udí, či už vo väčšej alebo menšej miere, najmä v prípadoch, ked' sa niekam potrebovali dostat', a pri prístupe $\mathrm{k}$ informáciám. Cestovanie bolo problematické aj pre tých participantov, ktorí boli zvyknutí chodievat' sami, zmieňovali sa napríklad o komplikáciách pri cestovaní vo večerných hodinách. Ako limitujúce popisovali aj neprispôsobenie informačného obsahu, napríklad $\mathrm{v}$ televízii alebo na webových stránkach, potrebám zrakovo postihnutých. Participantom chýbala aj nejaká osoba, s ktorou by mohli pravidelne trávit' vol'ný čas, pretože napríklad ich rodinní príslušníci boli pracovne vyt'ažení. Väčšina participantov však mala vytvorený taký okruh aktivít, ktorým sa vzhladom na svoje postihnutie venovat' mohli aspoň čiastočne, a $\mathrm{k}$ problémom, ktoré sa $\mathrm{v}$ ich vol'nom čase objavovali, sa snažili pristupovat' pragmaticky.

Výskumy, ktoré sa zaoberali vol’ným časom seniorov so zrakovým postihnutím ukázali, že vol'nočasové aktivity sa významnou mierou spolupodiel'ali na utváraní zmyslu života týchto jednotlivcov. Vykonávanie aktivít však od nich vyžadovalo vynaložit' väčšie úsilie, a spokojnost's týmito aktivitami bola nižšia. Významný bol pre nich kontakt s druhými lud'mi, ktorý však nebol naplnený do takej miery, ako by si priali. Zároveň pocitovali zvýšenú závislost' od svojho okolia. Niektorým záujmom sa v dôsledku straty zraku nemohli d’alej venovat', a rozsah sociálnych, fyzických aj mentálnych aktivít, na ktorých participovali, sa tým pádom znížil (Berger, 2011; Stevens-Ratchford, Krause, 2004).

Poznatky vyplývajúce $\mathrm{z}$ uvedených štúdií korešpondujú so zisteniami, ktoré vychádzajú z nami realizovaného výskumu. Vol’ný čas a aktivity realizované počas neho mali pre participantov vel'ký význam, avšak nie všetky jeho aspekty spín̆ali ich predstavy. Zo zrakového postihnutia vyplývali pre túto sféru rôzne negatíva, podla participantov to bola predovšetkým nemožnost' vykonávat' oblúbené činnosti, závislost' na druhých l'ud'och, st'ažený prístup k informáciám, či zhoršená možnost' cestovania. 
Odchod z práce predstavuje pre jednotlivca kompletne novú situáciu. Mení sa tým aj koncept samotného vol'ného času. Zo štúdie, realizovanej Roadburgom v 80. rokoch minulého storočia, ktorý skúmal vol'ný čas skupiny seniorov vyplynulo, že bežné vnímanie vol’ného času v zmysle slobody/oslobodenia od práce sa väčšiny starších l'udí netýka, ked’že spravidla už nie sú zárobkovo činní. Vol’ný čas participanti v tomto výskume chápali najmä v zmysle potešenia a relaxácie. Vyše 80 percent z nich uviedlo, že vol'no majú celý deň, a preto sloboda/oslobodenie už pre ich vol'ný čas nebola určujúcou charakteristikou (Driedger, Chappell, 2014).

Vel'ké množstvo vol'ného času, ktoré však človek nadobudne po odchode zo zamestnania, však so sebou prináša aj isté riziká. Podstatná je totiž najmä kvalita, nie kvantita. Ako sa vyjadrila jedna participantka: „Mám fakticky vol’ný celý deň, lenže ako ho využijem? Niekedy mi je l'úto toho času, že ho len tak premárnim ...mohla by som niečo robit', ale nerobím nič." Problémom niekedy môže byt', že títo jednotlivci, či už v dôsledku zrakového postihnutia, alebo nejakej okolnosti, ktorá súvisí so starnutím, nemajú taký dobrý prístup $\mathrm{k}$ možnostiam, alebo nemajú až takú motiváciu, a funkcie vol'ného času - teda potešenie a relaxácia, ktoré sa uvádzali vo vyššie spomínanom výskume, nedokážu dosiahnut' na takej úrovni, ktorá by viedla $\mathrm{k}$ ich spokojnosti. $\mathrm{S}$ tým súvisí téma, ktorá sa objavovala vo výpovediach participantov, a je ňou potreba zmyslu, prípadne užitočnosti.

Ďalšia významná téma, ktorá vyplynula z výskumu, bola potreba sociálneho kontaktu. Podl'a Aulda a Casea (1997) sociálna interakcia je jeden z najčastejších dôvodov, pre ktorý l'udia realizujú vol'nočasové aktivity. S týmto tvrdením sa na základe poznatkov získaných z nášho výskumu stotožňujeme. Dôležitost' medzil'udského kontaktu rezonovala vo výpovediach participantov a rôznymi spôsobmi vplývala na ich vol'ný čas. Trávit' čas s rodinou, kamarátmi, či známymi pre nich malo vel'ký význam a v prípade, že žiaduca úroveň sociálneho kontaktu nebola naplnená, odrazilo sa to na spokojnosti participantov. Sociálna interakcia nemusí byt' len ciel'om vol'nočasovej činnosti, ale medzil'udský kontakt je vel'mi dôležitý aj ako motivácia k realizácii aktivít, a jeho chýbanie či nedostatok často negatívne vplývalo na mieru aktivity jednotlivcov.

Nesmierne dôležitým faktorom, ktorý sa tiež podiel'a na vnímaní vol'ného času, je postoj $k$ svojmu zrakovému postihnutiu. Súhlasíme s Melillo (2007 in Houde, 2007), ktorá uvádza, že to, ako senior so zrakovým postihnutím vníma stratu zraku, ovplyvňuje jeho sebavedomie, životnú spokojnost', úspešné starnutie a kvalitu života. Dôležité je aj to, či priebeh zrakového postihnutia má náhly alebo postupný charakter.

$\mathrm{V}$ priebehu interview zazneli rôzne vyjadrenia $\mathrm{k}$ tejto téme, ktoré nám priblížili, ako sa participanti $\mathrm{k}$ postihnutiu a $\mathrm{z}$ neho plynúcim dôsledkom stavajú. Participanti prejavili racionálny prístup a snahu akceptovat' realitu takú, aká je. Samozrejme, dosiahnut' tento stav nejde hned', predchádza mu proces adjustácie, ktorý môže trvat' rôzne dlhý čas. Bolo zrejmé, že si uvedomujú, aké je dôležité neupadat' do sebal'útosti, snažit' sa byt' aktívny a tešit' sa $z$ pozitívnych vecí, ktoré život prináša.

Miera adaptácie na zrakové postihnutie ovplyvňuje takmer všetky aspekty života jednotlivca so zrakovým postihnutím. Jedným z faktorov, ktoré sa podiel'ajú na úspešnosti adaptácie na túto životnú zmenu je aj čas, ktorý od jej nástupu uplynul. Participanti, ktorí sa podiel'ali na našom výskume, žili so zrakovým postihnutím už dlhší čas, a preto mali vyššiu pravdepodobnost', že ich emócie a osobnostné charakteristiky už budú ustálenejšie. Domnievame sa, že ak by sme tento výskum realizovali s l'ud'mi, pre ktorých je zrakové postihnutie čerstvá životná udalost', bolo by vel'mi pravdepodobné, že by sme dospeli k úplne iným výsledkom. 
Zrakové postihnutie so sebou vnáša do oblasti vol’ného času množstvo zmien, ktoré sú väčšinou prijímané hlavne ako zmeny negatívneho charakteru. To však neznamená, že človeka, ktorý stratí zrak, už nečaká nič príjemné. Strata zraku núti jednotlivca zamysliet' sa nad tým, čo je podstatné v jeho živote, často dochádza k zmene rebríčka hodnôt. Prirodzene, najprv je potrebné prejst' procesom adaptácie, ktorý prebieha u každého človeka špecifickým spôsobom a môže trvat' rôzne dlhú dobu. Potom však môže aj prostredníctvom vol'nočasových aktivít opät' dosiahnut' spokojnost'. Vel'mi pekne to vystihol jeden z participantov: ,....strata zraku je silný zásah do života človeka, že tam sú iba dve možnosti. Jedna možnost', že akceptuje dotyčný túto novú vec, tento stav, alebo neakceptuje, a bude bojovat'. Ale v tom druhom prípade je ten človek odsúdený na večné týranie seba samého samým sebou. V tom prvom prípade môže nájst' konštruktívny priestor, kde môže sa cítit'vel'mi dobre, ba dokonca ešte lepšie, ako ked' videl. “

Napriek ich vlastnej snahe prežívat' svoj vol'ný čas kvalitne sa mnohí participanti stretávali $\mathrm{s}$ problémami, ktoré pramenili $\mathrm{z}$ vonkajšieho prostredia, a zahŕňali najmä nepochopenie okolia, nedostatočnú úroveň prístupu k informáciám, či bariéry vo fyzickom prostredí. Tieto prekážky participantom znepríjemňovali trávenie vol'ného času, ako aj celkové každodenné fungovanie. Jedna participantka sa vyjadrila: ,je taká určitá nevšimavost' medzi l'ud'mi, kde človeka to aj zamrzí. "

Globálnym fenoménom dnešnej doby je starnutie populácie, teda zvyšovanie podielu starších l'udí v rámci populácie. Tento proces vnáša do spoločnosti mnohé zmeny, najmä v sociálnej a ekonomickej oblasti, ktoré predstavujú pre vlády jednotlivých krajín vel'kú výzvu. Starších l'udí pribúda, a ked’že s vekom narastá výskyt zrakového postihnutia, riziko jeho vzniku sa týka väčšieho počtu l'udí. Hoci situácia sa pod vplyvom intenzívnejšej osvety a mediálnych výstupov zlepšuje, a niektorí participanti sami uvádzali pozitívne skúsenosti, myslíme si, že stále je vel'a vecí, ktoré by bolo potrebné doriešit' a skvalitnit'.

\section{References}

Alma, M. et al. (2011). Participation of the elderly after vision loss. Disability and Rehabilitation, Vol, 33, no. 1, 63-72. [in English].

Auld, Ch. J., Case, A. J. (1997). Social Exchange Processes in Leisure and Non-leisure Settings: A Review and Exploratory Investigation. Journal of Leisure Research, Vol 29, no. 2, 183-200. [in English].

Berger, S. (2011). The Meaning of Leisure for Older Adults Living with Vision Loss. OTJR: Occupation, Participation and Health, Vol. 31, no. 4, 193-199. [in English].

Cory, P. (2001). Elementary Rehabilitation for Seniors Who Lose Sight Late in Life, In: Wahl, H. W., Schulze H. E. On the Special Needs of Blind and Low Vision Seniors: Research and Practice. Amsterdam: IOS Press. [in English].

Crews, K., Campbell, V. (2004). Vision impairment and hearing loss among communitydwelling older American: implications for health and functionig. Am J Public Health, Vol. 94, no. 5, 823-829. [in English].

Depp, C., Jeste, D. (2006). Definitions and predictors of successful aging: a comprehensive review of larger quantitative studies. Am J Geriatr Psychiatry, Vol. 14, no. 1, 6-20. [in English].

Driedger, L., Chappell, N. L. (2014). Aging and Ethnicity: Toward an Interface. Oxford: Butterworth-Heinemann. [in English]. 
Dumazedier, J. (1966). Volný čas. Sociologický časopis / Czech Sociological Review, 2 (3), 443-447. [in Czech].

Gerinec, A.(2005). Detská oftalmológia. Martin: Osveta. [in Slovak].

Hájek, B., Hofbauer, B., Pávková, J. (2008). Pedagogické ovlivňování volného času: současné trendy. Praha: Portál. [in Czech].

Jakabčic, I. (2002). Základy vývinovej psychológie. Bratislava: Iris. [in Slovak].

Klevetová, D., Dlabalová, I. (2008). Motivačni prvky při práci se seniori. Praha: Grade Publishing. [in Czech].

Kratochvílová, E. (2010). Pedagogika volného času. Výchova v čase mimo vyučovania v pedagogickej teórii a praxi. Trnava: Typi Universitatis Tyrnaviensis. [in Slovak].

Lopúchová, J. (2011). Základy pedagogiky zrakovo postihnutých. Bratislava: Iris. [in Slovak]. Mühlpachr, P. (2004). Gerontopedagogika. Brno: Masarykova univerzita v Brné. [in Czech].

Oláh, Z. (2005). Oftalmológia v kocke. Bratislava: Pol'ana. [in Slovak].

Pávková, J. et al. (2001). Pedagogika volného času: teorie, praxe a perspektivy mimoškolní výchovy a zařizení volného času. Praha: Portál. [in Czech].

Phoenix, C., Griffin, M., Smith, B. (2015). Physical activity among older people with sight loss: a qualitative research study to inform policy and practise. Public Health, Vol. 129, no. 2, 124-130. [in English].

Ponchillia, P. E., Ponchillia, S. K. V. (1996). Foundations of Rehabilitation Teaching with Persons who are Blind or Visually Impaired. New York: American Foundation for the Blind. [in English].

Pressman, S. et al. (2009). Association of enjoyable leisure activities with psychological and physical well-being. Psychosom Med., Vol. 71, no. 7, 725-732. [in English].

Průcha, J. Walterová, E., Mareš, J. (2003). Pedagogický slovník. 4. aktualizované vydání. Praha: Portál. [in Czech].

Roelofs, L. (1999). The meaning of leisure. Journal Gerontol Nurs, Vol. 25, no. 10, 32-39. [in English].

Scheiman, M., Scheiman, M., Whittaker, S. (2007). Low Vision Rehabilitation: A Practical Guide for Occupational Therapists. New Jersey: SLACK Incorporated. [in English].

Sosna, T. (2009). Diabetická retinopatia. Med. Pro Praxi, Vol 6, no. 5, 270-275. [in Czech].

Stevens-Ratchford, R., Krause, A. (2004). Visually Impaired Older Adults and Home-Based Leisure Acitivities: The Effects of Person-Environment Congruence. Journal of Visual Impairment \& Blindness, Vol. 98, no. 1, 14-27. [in English].

Stuart-Hamilton, I. (1999). Psychologie stárnutí. Praha: Portál. [in Czech].

Vágnerová, M. (2008). Vývojová psychologie II. Dospělost a stář́. Praha: Karolinum. [in Czech].

Wang, Ch.-W., Chan, C. L. W., Chi, I. (2014). Overview of Quality of Life Research in Older People with Visual Impairment. Advances in Aging Research, Vol. 3, no. 2, 79-94. [in English].

WHO. (2015). World report on aging and health. [Electronic resource]. Retrieved from http://apps.who.int/iris/bitstream/10665/186463/1/9789240694811_eng.pdf?ua=1. [in English]. 